Vol. 9, n 1 | 2005

Varia

\title{
Crime and Punishment: 10 years of research (1)
}

Filling in, adding up, moving on: Criminal Justice History in

Contemporary Britain

\section{Clive Emsley}

\section{(2) OpenEdition \\ 12 Journals}

Electronic version

URL: https://journals.openedition.org/chs/387

DOI: $10.4000 /$ chs. 387

ISSN: 1663-4837

Publisher

Librairie Droz

\section{Printed version}

Date of publication: 1 July 2005

Number of pages: 117-138

ISBN: 978-2-600-01014-6

ISSN: 1422-0857

\section{Electronic reference}

Clive Emsley, "Crime and Punishment: 10 years of research (1)", Crime, Histoire \& Sociétés / Crime,

History \& Societies [Online], Vol. 9, $n^{\circ} 1$ | 2005, Online since 16 February 2009, connection on 23 March 2022. URL: http://journals.openedition.org/chs/387 ; DOI: https://doi.org/10.4000/chs.387

This text was automatically generated on 23 March 2022.

(c) Droz 


\title{
Crime and Punishment: 10 years of research (1)
}

\author{
Filling in, adding up, moving on: Criminal Justice History in
}

Contemporary Britain ${ }^{1}$

\section{Clive Emsley}

1 Thirty years ago the history of crime, criminal justice, penal policy and penal institutions in Britain was a subject scarcely explored by academics. Such work as had been done was generally informed by a Whiggish perspective. It saw legal, police and prison developments as following a generally enlightened, humanitarian and progressive trajectory. It understood criminals from an essentially positivist perspective. The laws, the courts, the police, the prisons were there to protect ordinary people from the criminal «other». In the 1960s and 1970s the enthusiasm for history from below began to whittle away at the broad Whiggish assumptions. It was hoped that court records would provide a way in to hearing the voices of the poor, the artisans, the working classes who had left little evidence of their lives in what had been, until then, the usual corpus of historical source material. It was also assumed by many of the early researchers into this new form of social history that property crime might be a response to new attitudes towards property and to new work practices. For this reason much of the research focussed on the eighteenth century and the period of industrialisation. The other area of considerable interest was the seventeenth century; also a significant period of capitalist development, as well as one of war and revolution with a fair sprinkling of popular protest.

2 Now, in contrast, there is a considerable amount of published research into crime and the development of the criminal justice system in Britain. Much of it challenges the old Whig perspective. This recent research has been informed particularly by the theoretical work of Michel Foucault and Norbert Elias which became available for the invariably (and notoriously) monoglot British during the 1970s. Over the last ten years the history of British criminal justice has been concerned with the usual filling of gaps in knowledge and with reassessing different forms of source material. There has also been a significant shift in the direction of research away from property crime and 
towards the study of violence, at least with reference to the eighteenth and nineteenth centuries where property crime often formed the focus of the debates and research. The terms I have used to categorise the new work in the history of crime, criminal justice and penal policy - filling in, adding up and moving on - are not exclusive. They are intended essentially as a way of ordering the material and enabling a discussion of what has been achieved, what new directions have opened up and what may yet be done. Finally, by way of introduction, a caveat: my own interests focus largely on the period from the mid-eighteenth century and what follows essentially reflects my interests. There has been important and significant work on earlier periods. I would single out four books here by reputation and by comments from colleagues who know the medieval and early modern areas. First, Richard Fletcher's important study of a blood feud that continued among the Anglo-Saxon nobility over three generations before the Norman Conquest. Whether a feud that started with a massacre apparently sanctioned by a king can properly be considered in the context of criminal justice history might be open to dispute. Nevertheless, Fletcher's analysis of the incident provides important insights into understanding attitudes towards the use of violence and killing among the ruling elite of the period ${ }^{2}$. Malcolm Gaskill picks up on this latter issue with his exploration of how crime provides an insight into the mentalities of English people from the mid-sixteenth to the mid-eighteenth centuries ${ }^{3}$. Third among these books is the ground-breaking collection edited by Jenny Kermode and Garthine Walker on women and crime during the sixteenth and seventeenth centuries ${ }^{4}$. Finally, for the early modern period, it is important to single out James A. Sharpe's deconstruction of an remarkably well-documented trial for witchcraft during the reign of James $\mathrm{I}^{5}$. The article that follows here, unfortunately but of necessity, takes the period from the mid-eighteenth century for its focus.

\section{Filling in}

3 The early work during the 1970s and 1980s settled the basic historical outline of developments in crime, policing and penal policy in Britain and provided considerable detail. However, several of its important initial premises were not explored as fully as they might have been. The potential relationship between acquisitive crime and the growth of capitalism and of the factory system are the most obvious examples. In the last decade research into these issues has begun to generate some positive results. Barry Godfrey, most notably, has looked at theft from the factory, particularly from worsted factories in the West Riding of Yorkshire where local employers were so concerned about the problem as to create their own police. These private police present a problem for the old argument that links the early nineteenth-century development of borough and county police forces with the growth of capitalist industry. In some instances it seems clear that the private police were greatly preferred by local industrialists as cheaper, more efficient and easier to control. Godfrey also demonstrates that, contrary to much contemporary opinion and to the opinions of subsequent legal historians, some employers who also served as magistrates had no qualms about using their judicial authority against workers in their employ. At the same time, he suggests that it would be difficult to label factory theft as worker protest against the new work relationships and practices. Indeed, in some instances, stolen raw materials were actually sold on to smaller employers and this ensured that their factories were able to keep going in difficult times. Finally, Godfrey also casts some 
doubt on the notion that the factory was a more secure system for the prevention of theft than the old practices of outwork ${ }^{6}$.

Much of the early research picked up on the idea that the traditional customs of the workplace that involved the worker holding on to used raw materials for his or her own profit was increasingly criminalised during the eighteenth-century. Thus, when weavers held on to «thrums», carpenters to «chips», tailors to "cabbage», and so forth, as the workers labelled these perks, they found themselves more and more likely to be prosecuted for embezzlement. Such customs did decline during the nineteenth century, though the extent to which this was brought about by a concerted effort to criminalise such behaviour must remain an open question. At the same time, however, the growth of sophisticated joint-stock companies and the increasing numbers of clerks and shop workers dealing with money that was not their own provided new opportunities for workplace crime ${ }^{7}$. Randall McGowen has drawn attention to the eighteenth-century concerns about fraud and the passage of new capital legislation to deal with it ${ }^{8}$. A cluster of doctoral dissertations and articles have also taken up the shifting interpretation of embezzlement over the period, the problems of legislating against it, and the understanding of, and theoretical fuzziness of the concept of "white collar» crime when dealing with, among others, bankers, tax evaders, tax collectors and railway clerks 9 .

5 Much petty workplace crime during the eighteenth and nineteenth centuries was tried summarily before magistrates sitting in petty sessions. The growth of summary jurisdiction was something that stood out even for the early researchers into crime, yet initially there was very little research into the work of these courts. This is now being rectified and a series of useful essays have appeared, most notably that by Peter King, which stress how the courts were used by a cross-section of the community and undermines some of the earlier assumptions about the law functioning principally as a control mechanism in a bipolar society ${ }^{10}$. It is apparent that the summary courts became much more formal as the nineteenth century progressed, even so the practice of arbitration by the magistrates continued and the precise details of the change and the pattern of that change await detailed research.

6 The issue of juvenile crime was a topic that has interested researchers from the beginning of the new academic interest in the history of crime. Heather Shore's Artful Dodgers is an important recent addition here ${ }^{11}$. Building on earlier work Shore demonstrates that, while youthful offenders were not new in the early nineteenth century, the development of a specific concept of such an offender, particularly in legal discourse, was new. Some of her findings may have been expected. Such offenders were, for example, usually committed petty theft, they were generally male and their families were poor. But she also shows that their families were often struggling to be respectable and despaired about their unruly sons, something that does not fit with the late Georgian and early Victorians assumptions. Amongst the most interesting sources that she mines are the interviews conducted in the late 1830 s by the moral entrepreneur William Augustus Miles with juvenile offenders held on the Euryalus prison hulk.

7 Shore's juvenile law-breakers were overwhelmingly male, as with most criminal offenders. Pamela Cox has taken up the gendered perception of juvenile deviance in an illuminating fashion for the first half of the twentieth century. She suggests that assumptions about the modern world offering girls more licence fostered welfare 
policies which, through their intrusiveness and surveillance, served to produce deviance ${ }^{12}$. As will be discussed below, gender and crime has become a key topic in much of the recent work. Much of this work, however, has focussed on violent crime and there still remains much to be done in assessing the role of women as petty thieves and receivers, rather than as prostitutes, murderesses or victims ${ }^{13}$. There is also much to be done in explaining the patterns of judicial leniency towards female offenders during the eighteenth and nineteenth centuries ${ }^{14}$.

8 For crime in general, there still remains much detail to fill in and that there are ample, relatively untouched archival resources to enable this has recently been demonstrated by, for example, the work of Gwenda Morgan and Peter Rushton, of David Taylor, and of Timothy Shakesheff ${ }^{15}$. Shakesheff has produced a study of crime and protest in Herefordshire that complements John Archer's earlier, path-breaking work on rural arson, poaching and animal maiming in East Anglia ${ }^{16}$. The two books now challenge the traditional view of an oppressed, fatalistic and submissive agricultural workforce in the period following the Swing disorders of 1831. Shakesheff returns to the concept of social crime and stresses its value for understanding the attitudes of his labourers, sometimes «mad», sometimes «bad», and almost always «sad». They extended at least tacit support to a range of offences directed against their masters. At the same time farmers and landowners often showed considerable restraint in prosecuting these cases, and magistrates were often lenient in the punishments that they meted out, though this might have been as much in self-interest as over any concern for their labourers» plight. But while Shakesheff has highlighted crime going hand-in-hand with protest on the land, Archer's new focus in Lancashire has pointed to poachers who, rather than being hard-pressed agricultural labourers, were drawn from violent, urban criminal gangs ${ }^{17}$.

9 Morgan, Rushton and Taylor have shifted the geographical focus of much of the earlier work from a concentration on London, or at least the south, to the north east of England. Morgan and Rushton present a broad survey of crime and punishment in the north-eastern counties of Northumberland and Durham during the eighteenth century. There were few big towns; the port of Newcastle upon Tyne and the city of Durham, the centre of the old bishopric, were exceptional. This was a largely rural and sparsely populated region, but already showing some moves towards significant industrialisation with its growing coal trade and turbulent pitmen. The book fills in the gaps in our knowledge about crime and penal policy in the area. Essentially the situation does not appear to have been greatly different from elsewhere in the country. Theft, generally on a small scale, was the principal offence to come before the courts, and while there appear to have been loose networks of offenders, the fears of contemporaries about large criminal gangs appear to have been unfounded. Perhaps the most striking thing to emerge from the book is the early, relatively common use of imprisonment as a punishment in the area, well before the publication of the significant Enlightenment treatises on the subject. Morgan and Rushton's book is also important for being one of the first texts to give careful consideration to the issue of gender and crime, something that, as will be discussed below, has become a key issue in the most recent work. David Taylor's book looks at crime and policing in Middlesbrough, a town that was created as a centre for the heavy industry of the industrial revolution. In 1800 Middlesbrough was a dot on the map of North Yorkshire with four houses and twenty-five people. Three-quarters of a century later it was home to 40,000 inhabitants and providing work in iron foundries, engineering and 
shipbuilding. It was a turbulent, frontier town for much of its early life with a disproportionate population of young men who drank heavily and fought furiously both amongst themselves and with the new police. Taylor provides an illuminating case study of a unique town where respectable contemporaries manifestly had cause to hope that their new policemen would be domestic missionaries enforcing decorum and discipline if necessary with their batons.

10 The traditional Whig view was always that the policing of England before the reforms of the nineteenth century was composed of reluctant part-time constables and old, decrepit watchmen who could call the hour during the night but were useless at preventing crime or pursuing offenders. This view began to look untenable at a relatively early stage of the new research. In the last decade, however, the work of John Beattie, Andrew T. Harris and Elaine Reynolds has significantly undermined it with reference to London. The focus of both Beattie and Harris is on the square mile of the old City of London. Beattie shows how, more than a century before the muchcelebrated reforms of Sir Robert Peel, the policing institutions of the City were transformed in response to the expansion of the metropolis and the emergence of a new form of polite urban culture ${ }^{18}$. Harris continues the story drawing particular attention to the interplay between different levels of the City government and the worries over who should have control of constables and watch. The question of control over these police officers, Harris suggests, was as important to contemporaries as concerns about the nature of crime $^{19}$. Reynolds charts the emergence of paid, professional, supervised and relatively effective watches within the old parish structures of eighteenth-century London beyond the City proper. Problems for the developing system began to emerge as a result of the enormous taxes imposed during the Revolutionary and Napoleonic Wars. The inhabitants of the wealthier parishes were better able to cope than their poorer neighbours; the idea of the government relieving them of the burdens of responsibility and sharing out the finances appealed to many. But there was considerable annoyance that, while the localities of London were taxed to pay for the new police, they were deprived of all control over them ${ }^{20}$. The next generation of researchers needs to follow up this work with detailed assessments of policing in some of the principal towns of eighteenth-century England. Francis Dodsworth has hinted at what might be done with his use of Manchester archives, but the real purpose of his essay on «civic» police in eighteenth-century England is to show how the posts of constable and magistrate particularly were situated within a concept of civic duty. Public service for the eighteenth-century Englishman was an obligation upon citizens of a free state and these ideas were filtered through into the rigorous standards of behaviour imposed on the new police in the nineteenth century ${ }^{21}$.

11 Some of the most important early research to be published on crime and policing during the industrial revolution was the work, independently of each other, of David Philips and Robert D. Storch. More recently they have combined their talents to develop further the history of policing in England. First, they published an article that showed the British government to have been considering a national police force in the early $1830 \mathrm{~s}^{22}$. Second, they produced an important monograph detailing the emergence of policing in the English provinces in the second quarter of the nineteenth century ${ }^{23}$. Their extensive research in national and local archives prompts the conclusion that the permissive legislation of 1839 and 1840 was much more productive of change in provincial policing than has often been suggested. This leads to the additional conclusion that, at a time when the rural elites were losing power to central 
government, in this instance at least they enhanced their authority with their responsibility for the new police. In the end, however, provincial policing became increasingly drawn into the net of central government. With the legislation of 1856 central government began its system of inspecting all forces and paying part of the costs towards those deemed efficient by the new inspectorate- Her Majesty's Inspectors of Constabulary who reported annually to parliament. But the interplay of central and local was to remain a key element in the development of policing in England throughout the nineteenth and twentieth centuries.

12 A different kind of interplay involving central government, the police and local actors has been explored by Stefan Petrow ${ }^{24}$. In Petrow's book the focus returns to London. The Metropolitan Police were the only English police institution directly responsible to central, as opposed to local government. Petrow's aim is to assess how the Metropolitan Police and their masters in central government dealt with the demands and campaigns of social purity groups and with the concerns of those who feared the growth of police espionage and inquisitorial powers that they presumed existed on continental Europe. A further novel contribution to the history of policing has been made by Haia ShpayerMakov with her analysis of the Metropolitan Police of London as a body of working men. It was, she emphasises «not only ... the largest such force in the country, policing the biggest city in Europe and the hub of an expanding empire, it was also one of the largest work organisations of any kind $»^{25}$. Its commanders had to develop new systems of management, to define carefully the ideal policeman for recruitment purposes, and to formulate the necessary rewards and systems of assessment and control that were needed to organise and maintain such a body. But, as already noted, London was a special case.

What is needed now are some detailed analyses along the lines set out by both Petrow and Shpayer-Makov that focus on provincial forces. Chris A. Williams has made some moves in this direction with several important essays on the policing of the great cutlery-producing city of Sheffield during the mid-nineteenth century. He explores the ways in which urban reform and police powers were intertwined and how a group of urban radicals developed a critique of criminal justice and plans for police organised at ward level within the city ${ }^{26}$. Taylor's study of Middlesbrough suggests that the local watch committee was content to leave its head constables to get on with the day-to-day running of the police. But watch committees of the towns could wield considerable power; they could have the last say on recruitment and discipline issues. When filled with moral reformers, as in Liverpool in the 1890s, they could compel a head constable to take action that he deemed to be inappropriate and fruitless - in this instance an order to close down all of the city's brothels on the assumption that this could stamp out vice. Some men appear to have served on the watch committees for many years and could have had as much, or even more detailed knowledge of police management and policing policy than some of the chief officers in their force. But the watch committees await detailed investigation. Details of how county police committees of magistrates functioned in relation to their chief constables also await research; as do the standing joint committees of magistrates and elected county councillors that replaced these magistrates-only bodies in 1888 . There is, however, a useful analysis of the social origins of the chief constables of England and Wales since the mid-nineteenth century that traces their shift from representatives of local power to an elite group of administrators with direct links to central government ${ }^{27}$. 

introduction into the criminal justice system. Peter King's Crime,Justice and Discretion in England 1740-1820 presents an important reappraisal of the criminal justice system in England on the eve of the major reforms of the early nineteenth century ${ }^{28}$. King uses the metaphor of a long corridor of inter-connecting rooms to describe the system. Each room, a judicial space moving from pre-trial procedures to punishment, had a different shape according to legal constraints and customary expectations. The accused might leave the corridor at any point depending on a variety of factors, not the least of which was the discretion of the accuser, usually a victim. King has no doubt that the law was slanted against the poor and he stresses the role of the middling sort as both victimprosecutors and jurors. He argues, convincingly, that the law was never an instrument that could be deployed solely in the interests of the property-owning elite. Victimaccuser-prosecutors, jurors, judges and others massaged situations to achieve what they as individuals or as groups saw as a fair resolution to an offence. All classes used the law, and it became an arena of struggle and negotiation within which accommodation seems to have been far more common than the kind of mystification stressed many years ago by Douglas Hay ${ }^{2}$.

A key development in the English criminal trial during the eighteenth century was the appearance of defence counsel, and the beginnings of the trial as an adversarial contest between legal professionals. This has been chronicled and analysed by David J.A. Cairns, John H. Langbein, and Allyson N. May. Langbein shows that, following some notorious cases in the late seventeenth century during which individuals were convicted and executed for treason on perjured evidence, defence counsel were introduced to assist individuals accused of this offence. During the 1730s judges extended the procedure to felony trials. They did this for the best of motives. There was an increasing use of lawyers in the conduct of prosecutions and this appeared to put defendants at a disadvantage. At the same time, the use of blood money rewards and the opportunities for accomplices to turn to King's evidence, seemed to present a greater likelihood of false witness and perjured evidence. However, Langbein argues that the defence counsel gradually led to the silence of the accused in the court and to new burdens of proof being placed on the prosecution. The unfortunate result of well-meaning changes introduced to assist the defendant, was a system that «failed to develop institutions and procedures of criminal investigation and trial that would be responsible for and capable of seeking the truth ${ }^{30}$. May's concern is specifically the development of the bar at the Old Bailey from the late eighteenth to the mid-nineteenth century ${ }^{31}$. Her work fleshes out much of the argument to be found in Langbein. She shows that, while they were responsible for some significant changes in the development of the criminal trial, the barristers were not, as a body, committed to reform and did not show great concern for the rights of prisoners. Like Langbein, she also focuses on the debates about «truth" and «justice» in the both legal and the lay press in the period surrounding the Prisoners' Counsel Act of 1836 that finally permitted barristers to address the court on a defendant's behalf. Cairns covers some of the same ground but takes the story on to 1865 exploring the continuing debates about the adversarial system and also its implications for the procedure of criminal trials ${ }^{32}$.

One of the concerns acting upon the eighteenth-century English judges and highlighted by Langbein was the fact that individuals accused of felony faced the possibility of a capital sentence. One of the most passionate monographs touching on the history of 
crime and published during the last decade is V.A.C. Gatrell's The Hanging Tree ${ }^{33}$. The gradual replacement of barbaric public executions by more humane and rational systems of punishment was a common assumption in the old Whig view of criminal justice history. These assumptions took a severe battering from the theories of Michel Foucault and then with Michael Ignatieff's A Just Measure of Pain ${ }^{34}$. But this work, together with that of Margaret De Lacy, William Forsythe and Seán McConville, tended to focus more on policy and shifts in penal sanctions ${ }^{35}$. Gatrell does not eschew these issues, but his real interest is in exploring how the public execution was understood, how the executions were portrayed and the ways in which crowds, rather than polite and respectable commentators, responded. Along the way he suggests that humanitarianism and a new sensitivity were much less important in bringing about change. His stress on the pragmatism of politicians whose over-riding determination was to shore up the penal system has not gone unchallenged, however. His critics have drawn attention to real differences between Robert Peel and his predecessor over capital punishment and have stressed, once again, the significance of emotion and the humanitarian perspective among reformers ${ }^{36}$.

Randall McGowen is Gatrell's most subtle and tenacious critic and places particular emphasis on detailed analyses of what contemporaries said and wrote in the debates on capital punishment. He argues forcefully and convincingly, and in contradiction to the traditional Whig argument of a growing humanitarianism, that by the mid-nineteenth century a new confidence and vigour was apparent among those advocating the retention of capital punishment. The focus of the debate settled on the sanctity of human life and the need to preserve civilised society from the threat posed by those labelled as the "criminal class». The retentionists urged the consideration of the victim and the victim's family, and the requirement that the state enforce security for its citizens $^{37}$. The debates of the following century, which led ultimately to the abolition of the death penalty, have been reassessed by Victor Bailey with particular reference to the position of the Labour Party ${ }^{38}$.

Two other areas of punishment have also been valuably filled in and developed over the last decade. Gwenda Morgan and Peter Rushton have taken up Roger Ekirch's work on transportation to the American colonies during the eighteenth century. Their focus is primarily on variations in sentencing, what happened to the convicts once in the colonies, how many made it back home and in what ways ${ }^{39}$. Transportation to the Australian colonies is much better known, but Deborah Oxley has broken new ground with her monograph on the female convicts sent there ${ }^{40}$. Alyson Brown has also addressed the question of what happened to convicts in the context of their prison experience and the forms of protest and disturbance in English prisons between 1850 and $1920^{41}$.

\section{Adding up}

Adding up can be construed as the preparation of syntheses. There are now five broad survey texts drawing together the research into crime and penal policy in England. An «introductory history» put together by four authors, attempts with varying degrees of success to span the medieval to the modern periods ${ }^{42}$. A documentary source book was published subsequently to accompany this book ${ }^{43}$. The two volumes by, respectively, James A. Sharpe and Clive Emsley cover the mid-sixteenth to the beginning of the 
twentieth century ${ }^{44}$. A survey by David Taylor covers roughly the same period as Emsley and continues through to 1914, while that of Philip Rawlings covers three centuries from the Glorious Revolution of $1688^{45}$. Two books by David Jones cover the history of crime and policing in Wales during the nineteenth and twentieth centuries, though, given the extent to which they depend on archival research and Jones's towering presence in the area, it is rather misleading to consider them as syntheses ${ }^{46}$.

«Adding up» can also refer to the statistics of crime. As one of the syntheses notes:

Many of the key questions, certainly many of the most popular questions about crime, are quantitative. How much was there? Was it increasing or decreasing? Which types of crime were most prevalent at particular periods or in particular places? Even the central question: did economic and social change foster different kinds of criminality requires statistical evidence to hazard an answer ${ }^{47}$.

21 The new generation of historians of crime has always recognised the problems and difficulties inherent in the use of criminal statistics. Howard Taylor's work towards the end of the 1990s challenged the value of even the most cautious conclusions that had been drawn from statistical evidence.

The argument that the statistics said much more about policing than about crime has long been deployed. Setting the twentieth-century statistics alongside campaigns within the police service to demonstrate their worth and their need for better funding and improved wages, Taylor revealed that the incidence of crime increased alongside these campaigns ${ }^{48}$. Taking the statistics for an even longer period, namely from the mid-nineteenth century, he has argued that the figures really only reflect what the treasury was prepared to put in to the criminal justice system at any one time. Thus, he maintains, even with murder, the offence that has generally been regarded as the one where the statistics most closely match the actual incidence, the overall annual number was restricted since police forces, and the criminal justice system in general, were having to work within fixed budgets ${ }^{49}$. These arguments have not gone unchallenged. The most systematic critique is that presented by Robert M. Morris who suggests that Taylor's theory does not allow for the complexities of the decentralised and disaggregated character of the English criminal justice system. It is, for example, difficult to comprehend the mechanism by which more than one hundred separate police forces could collaborate to construct increases in crime within their respective jurisdictions at precise moments. Morris also denies that there is any evidence to suggest unbreakable budgetary ceilings for the finances of the criminal justice system. He does, however, concede that Taylor's work has drawn useful attention «to just how little some of the inputs [to the criminal justice system] have been studied, and how far the division and re-division of criminal business between the courts was manipulated $\aleph^{50}$.

Less immediately contentious than Taylor's work, but significant and important, is the analysis of the arrest statistics for mid-nineteenth-century Sheffield by Chris A. Williams. The conclusions of Williams's analysis suggest that during the early 1860s around one in five of the male population of Sheffield - a city noted for its artisan class working in the cutlery trades - had a criminal record. The crimes were rarely serious and were tried in the lower, summary courts administered by magistrates. But the sheer number of arrests adds weight to the early arguments of Robert Storch about policemen serving as domestic missionaries intervening often and regularly to impose new standards on the working class ${ }^{51}$. Working out from these conclusions Williams has 
suggested further how the categorisation and enumeration of separate crimes and types of offenders in the mid-nineteenth-century served to make the problems appear manageable and potentially solvable ${ }^{52}$.

\section{Moving on} 1990s there was a vociferous political campaign to provide pardons for the soldiers sentenced for cowardice and executed by firing squad during the First World War. The arguments were often emotional on both sides. They prompted books defending the British Army and stressing that it was fighting an unprecedented war at a time of a completely different mental world-view ${ }^{53}$. But they also prompted some rather more interesting research that related the military law to the criminal law and sought to explain, for example, the reasons why certain men were chosen as examples for the firing squad rather than others. Gerard Oram's work in particular has shown senior army officers deploying contemporary eugenicist thought to single out «worthless men» for execution. He has shown how the eighteenth-century system of «pious perjury» that prompted judges and juries to devalue goods in cases of theft to spare individuals from the death penalty had echoes in the courts martial during the war. Finally, he has contrasted the workings of the British Military Code with that of other combatant states ${ }^{54}$. The workings of military codes in other periods would benefit from further study. Similarly, the extent of ordinary criminality among servicemen in both peace and war remains significantly under-researched ${ }^{55}$.

Concerns about offences in which firearms are used generated considerable anxiety and draconian legislation in Britain during the 1990s. This prompted some research within the country, but the most provocative text was written by a historian resident in the United States. In Guns and Violence Joyce Lee Malcolm takes as her starting point the fact that, until the Declaration of Independence and the subsequent war, Britain and America lived under the same legal code and enjoyed the same legal rights. Since that period, she argues, while the Americans have preserved their right to bear arms, successive British governments of all political hues have systematically deprived their citizens of the right. She suggests further that the current difference in levels of crime in England and the United States, with violent crime, especially property crime, increasing in the former and declining in the latter, is directly linked with this policy ${ }^{56}$. The argument is thought provoking and has also been taken up by a polemicist of the radical right claiming to write «a history», but it is far from conclusive or convincing ${ }^{57}$. There were, for example, no restrictions on the purchase of guns in Victorian England, yet few appear to have availed themselves of the opportunity of acquiring such a weapon. When Englishmen, Welshmen, Scotsmen killed in the nineteenth and twentieth centuries, they appear perfectly satisfied with their fists, boots or even knives.

Contemporary concerns about child sex abuse and paedophiles underpin Alyson Brown and David Barrett's investigation of child prostitution and abuse since the close of the Victorian period ${ }^{58}$. In particular they draw attention to the discourses within which the problem was characterised and addressed, and which oftentimes, because of the sensitivity and controversial nature of the issue, concealed as much as they exposed of the problem. Brown and Barrett acknowledge a significant debt to a slightly earlier

Crime, Histoire \& Sociétés / Crime, History \& Societies, Vol. 9, $\mathrm{n}^{\circ} 1$ | 2005 
book by Louise Jackson which explores in detail how the sexual abuse of children was discovered, discussed and dealt with in Victorian and Edwardian England. There is considerable emphasis in Jackson's work on the different beliefs and codes of classes, neighbourhoods and the law, and also on the «apparent contradiction between the shock and horror that the notion of sexual abuse elicited and the readiness with which alleged abusers were acquitted or sentenced to fines and minor terms of imprisonment $»^{59}$. Jackson finds a resolution to the contradiction in the concept of respectability. The honest, hard-working man could not be perceived as a lustful abuser of an innocent child. At the same time she points to shifting perceptions of the child emerging in the early twentieth century that challenged the concepts of the innocent child and that gave rise to anxiety about «neuroses» in some children who developed sexual impulses and fantasies.

The recognition of gender as a serious conceptual subject for historians, together with the emergence of a cultural history drawing much of its inspiration from postmodernist thinking have both had a significant impact on the history of crime in the last decade. Prostitution, infanticide and wife-beating have been subjects of interest for historians of crime since the recent growth of academic interest in the area. Mark Jackson's work on the cases of infanticide brought before eighteenth-century assizes, particularly for the Northern Circuit, brings a new dimension to the understanding of illegitimacy and medical testimony during the period. It also extends our knowledge of the use of discretion by the courts and of debates about the administration of justice ${ }^{60}$. Jackson subsequently developed this work by editing a collection of essays on infanticide which, while the main focus remains England, has important comparative chapters on France, Germany and South Africa ${ }^{61}$.

28 A novel approach to the history of domestic violence, one that stresses the significance of spatial and social contexts, the rhythms and rituals of daily life and generational experience, is to be found in Shani D'Cruze's work on the petty courts of Lancashire and, to a lesser extent, Suffolk in the second half of the nineteenth century. D'Cruze rehearses some of the more recognised areas of the topic, such as the dangers within the home and the construction of an individual's identity within the courtroom. But she also points to the potential advantages for courtship, with its inherent risks, at the workplace, the potential for sexual exploitation at the workplace and within the robust plebeian leisure culture of the period that social historians have often tended to celebrate. Finally she delineates the various support networks available for injured women among both family and neighbourhood ${ }^{62}$. In a subsequent edited collection on the period 1850 to 1950 , D'Cruze brings together a series of short, and somewhat variable papers that revisit some of these issues, but which also point to the use of violence in the construction of some masculinities, particularly that of the workingclass «hard man» ${ }^{63}$. Perhaps the most significant researcher focussing on violent masculinity is Andrew Davies who has painstakingly reconstructed youth gangs in Manchester and Glasgow emphasising their conservative nature, their place in the lifecycle of the urban working class, their predominantly, but not exclusively, male composition $^{64}$.

29 Two historians have attempted broad surveys of violence in England. John Carter Wood argues that violence was «discovered» as a social problem in the late eighteenth and early nineteenth centuries as a traditional customary understanding that legitimated physical confrontation was challenged by an emergent middle - and upper-class 
culture that idealised propriety, rationality and self-restraint ${ }^{65}$. Clive Emsley takes a rather similar line but emphasises how notions of Englishness became intertwined with the understanding of violence in crime, politics, sport and other social exchanges over the two centuries from the mid-eighteenth century ${ }^{66}$. Interpersonal violence in the eighteenth century, and particularly how it related to changing ideas of masculinity, has been explored by Robert Shoemaker in a series of essays ${ }^{67}$. The most detailed and sustained analysis of male violence in Victorian England is that by Martin J. Wiener ${ }^{68}$. Men of Blood examines homicides committed by men, particularly those in which a woman was the victim, and the responses to these homicides by the courts and the wider population. Wiener argues that, while there was an increasingly sharp distinction made between the separate spheres of men and women during the Victorian period, this had the effect of criminalising male violence. In the new script that emerged in Victorian courtrooms the «innocence and weakness» of women fostered a greater severity against men who injured and killed. Wife killing was increasingly prosecuted as murder, and wife killers constituted an increasing number of those convicted and executed for murder. Occasionally juries and judges clashed over the understanding of the actions of the accused; but, possibly at a slower rate, juries too began to adopt the harsher line being taken by judges, as well as by civil servants and politicians in the Home Office. Wiener makes the tantalising and provocative suggestion that the protection of women in this way was at its most marked in the Victorian period, and gradually subsided during the twentieth century - a suggestion that deserves to be followed up with more research.

Wiener's work has important parallels with Anette Ballinger's passionate account of the 15 women executed for murder in England and Wales between 1900 and 1955. In the same way that Oram set out to establish what criteria led to men being executed from among those sentenced for cowardice during the First World War, Ballinger set out to establish the criteria that led to these women being denied clemency from the 130 or so actually sentenced to death for murder. She shows clearly that, in significant ways, each of the 15 failed to fulfil the gender expectations of women during the period. Those who «step furthest beyond the boundary of acceptable female conduct and behaviour» she concludes, «also receive the harshest form of punishment» ${ }^{69}$. Ballinger's 15 women used a variety of methods to kill their victims, during the nineteenthcentury, however, the popular perception was that murderesses invariably used poison. Katherine Watson's lively account of poisonings in England from the mid-eighteenth century to the First World War demonstrates that men were as likely to use poison as women. Drawing on the details of some 540 cases she interweaves motives with the availability of different poisons and the increasing abilities of the authorities to detect its use ${ }^{70}$.

The books of Ballinger, Shani D'Cruze, Louise Jackson and Martin Wiener are all informed by post-modern and cultural history perspectives. There are post-modernists and contemporary cultural historians who proclaim the centrality and significant of the text, apparently oblivious of the fact that careful textual analysis has always been central to the craft of the good historians. Such careful textual analysis, emphasising the context as well as the content has been significant in the work of those academics that have focused on the history of crime and criminal justice. There are good recent examples to be found in David Philips's biography of William Augustus Miles, a royal bastard and penal reformer who conducted a series of investigations into criminality in England during the 1830s and ended his days as head of the police in Sydney, Australia, 
in Philips's deconstruction of the theories of early nineteenth-century moral entrepreneurs, and in the late David Englander's essay on Henry Mayhew's analysis of the Victorian criminal classes ${ }^{71}$. Paul Lawrence, in turn, has begun to make comparative assessments of police memoirs in England and France to assess how officers in the two countries perceived and understood crime and the poor, and how they sought to present their own careers to the public ${ }^{72}$.

In addition to the use of some of the supposedly novel ideas of post-modernism, there has also been a considerable growth in twentieth-century history in Britain. Yet, to date, this has not yet had much impact on the history of crime and the criminal justice system. There are histories of policing that cover and, in some instances focus entirely on the twentieth century ${ }^{73}$. Louise Jackson has begun to illuminate the experience of women police officers and the welfare role to which they were largely confined during the inter-war period and the years immediately following the Second World War ${ }^{74}$. David Jones's last and posthumously published book assesses the pattern of crime and the changes in policing policies in South Wales across most of the twentieth century ${ }^{75}$. Donald Thomas looks at the pattern of crime and on specific kinds of offender during the Second World War, but this is a popular history geared more to telling interesting stories rather than presenting any detailed analysis of the overall impact of war ${ }^{76}$. Thomas is not concerned with the extent to which wartime patterns followed pre-war trends or continued after the conflict. For a broad summary of the pattern of crime and penal policy in the first half of the twentieth century there remains little more than a brief essay by Emsley and a discussion of the statistics of violent crime in his book on violence in England ${ }^{77}$. It is encouraging that some recent doctoral students have begun to address the issues for the twentieth century, and that the first fruits of their work is just beginning to appear in articles. Significant here is the work of Mark Roodhouse and James Whitfield. The former focuses on the Black Market during the Second World War, how it was policed and the extent to which new policing methods were continued after the war ${ }^{78}$. Whitfield paints a bleak picture of the Metropolitan Police after the war and assesses the impact that poor pay, low morale and depleted numbers among the police was to have on immigrants from the West Indies during the 1950s, 1960s and 1970s ${ }^{79}$.

It will be apparent that virtually all of the recent research discussed above concerns on England and Wales. This is not simply the result of an Englishman's myopia. It has become a common-place for English historians to begin discussions by stressing that they are focussing on England and Wales, emphasising that while Ireland had the English legal system, the English were generally perceived as alien occupiers, and that Scotland had a separate legal system. I have left such a comment to the end. There has been some interesting and important work on Ireland and Scotland. In particular Mark Finnane has assessed the statistics of criminal violence in Ireland while Carolyn Conley has focussed more closely on individual cases to chart the pattern and practice of interpersonal violence after the Great Famine ${ }^{80}$. Anne Crowther has published a stimulating assessment of the inter-relationship between English and Scottish law in the early nineteenth century and there has been some work, much of it still in the form of doctoral dissertations, on police development and on women as both the victims and the perpetrators of violence ${ }^{81}$. But one of the greatest gaps in the recent «British» research is the general lack of work on the history of crime and criminal justice in Scotland and Ireland. 


\section{BIBLIOGRAPHY}

\section{References}

Andrew, Donna T., McGowen, Randall, The Perreaus and Mrs Rudd: Forgery and Betrayal in EighteenthCentury London, Berkeley, Cal., University of California Press, 2001.

Archer, John E., By a Flash and a Scare': Arson, Animal Maiming and Poaching in East Anglia, 1815-1870, Oxford, Clarendon Press, 1990

Archer, John E., Poaching Gangs and Violence: The Urban-Rural Divide in Nineteenth-Century Lancashire, British Journal of Criminology, 1999, 39, 1, pp. 25-38.

Bailey, Victor, The Shadow of the Gallows: The Death Penalty and the British Labour Government, 1945-51, Law and History Review, 2000, 18, 2, pp. 305-349.

Ballinger, Anette, Dead Woman Walking: Executed Women in England and Wales 1900-1955, Dartmouth, Ashgate, 2000.

Barrett, Andrew, Harrison, Christopher, eds., Crime and Punishment in England: A Sourcebook, London, UCL Press, 1999.

Barrie, David G., Britain's Oldest Police? A Political and Social History of Policing in Glasgow, unpublished Ph.D thesis, University of Strathclyde, 2001.

Beattie, John M., Policing and Punishment in London 1660-1750: Urban Crime and the Limits of Terror, Oxford, Oxford University Press, 2001.

Briggs, John, Harrison, Christopher, McInnes, Angus, Vincent, David, Crime and Punishment in England: An Introductory History, London, UCL Press, 1996.

Brown, Alyson, Barrett, David, Knowledge of Evil: Child prostitution and child sexual abuse in twentiethcentury England, Cullompton, Willan Publishing, 2002.

Brown, Alyson, English Society and the Prison: Time Culture and Politics in the Development of the Modern Prison, 1850-1920, Woodbridge, Boydell Press, 2003.

Brown, Yvonne Galloway, Ferguson, Rona, eds., Twisted Sisters: Women, Crime and Deviance in Scotland since 1400, East Linton, Tuckwell Press, 2002.

Cairns, David J.A., Advocacy and the Making of the Adversarial Criminal Trial, 1800-1865, Oxford, Clarendon Press, 1998.

Colley, Robert, The Arabian Bird: A Study in Income Tax Evasion in Mid-Victorian Britain, British Tax Review, 2001, pp. 207-221.

Colley, Robert, The Shoreditch Tax Frauds: A Study of the Relationship between the State and Civil Society in 1860, Historical Research (forthcoming).

Conley, Carolyn, No Pedestals: Women and Violence in late Nineteenth-Century Ireland, Journal of Social History, 1995, 28, 4, pp. 801-818.

Conley, Carolyn, The agreeable Recreation of Fighting, Journal of Social History, 1999a, 33, 1, pp. $57-72$. 
Conely, Carolyn, Melancholy Accidents: The Meaning of Violence in Post Famine Ireland, Lanham, MD, Lexington Books, $1999 \mathrm{~b}$.

Corns, Cathryn, Hughes-Wilson, John, Blindfold and Alone: British Military Executions in the Great War, London, Weidenfeld and Nicolson, 2001.

Cox, Pamela, Shore, Heather, eds., Becoming Delinquent: British and European Youth 1650-1950, Aldershot, Ashgate, 2002.

Cox, Pamela, Gender, Justice and Welfare: Bad Girls in Britain, 1900-1950, Houndmills Basingstoke, Palgrave Macmillan, 2003.

Crowther, M. Anne, Crime, Prosecution and Mercy: English Influence and Scottish Practice in the early Nineteenth Century, in Connolly S.J., ed., Kingdoms United? Great Britain and Ireland since 1500: Integration and Diversity, Dublin, Four Courts Press, 1998.

Davies, Andrew, Youth gangs, masculinity and violence in late Victorian Manchester and Salford, Journal of Social History, 1998, 32, 2, pp. 349-369.

Davies, Andrew, These viragoes are no less cruel than the lads: young women, gangs and violence in late Victorian Manchester and Salford, British Journal of Criminology, 1999, 39, 1, pp. 72-89.

Davies, Andrew, Sectarian violence and police violence in Glasgow during the 1930s, in Bessel Richard, Emsley, Clive eds., Patterns of Provocation: Police and Public Disorder, New York \& Oxford, Berghahn Books, 2000.

D'Cruze, Shani, Crimes of Outrage: Sex, violence and Victorian working women, London, UCL Press, 1998.

D'Cruze, Shani, ed., Everyday Violence in Britain, 1850-1950: Gender and Class, London, Longman, 2000.

De Lacy, Margaret, Prison Reform in Lancashire, 1700-1850: A study in local administration, Manchester, Manchester University Press for the Chetham Society, 1986.

Devereaux, Simon, Peel, Pardon and Punishment: The Recorder's Report Revisited, in Devereaux, Simon, Griffiths, Paul eds., Penal Practice and Culture 1500-1900: Punishing the English, Houndmills Basingstoke, Palgrave, 2004.

Dodsworth, Francis, «Civic» police and the condition of Liberty: the rationality of governance in eighteenth-century England, Social History, 2004, 29, 2, pp. 199-216.

Duffield, Ian, Bradley, James, eds., Representing Convicts: New Perspectives on Convict Forced Labour Migration, London, Leicester University Press, 1997.

Eder, Markus, Crime and Punishment in the Royal Navy of the Seven Years' War, 1755-1763, Aldershot, Ashgate, 2004.

Ekirch, A. Roger, Bound for America: The Transportatin of British Convicts to the Conies, 1718-1775, Oxford, Clarendon Press, 1987.

Emsley, Clive, The English Police: A Political and Social History, $2^{\text {nd }}$ edition, London, Longman, 1996.

Emsley, Clive, Crime, Police and Penal Policy, in Wrigley, Chris ed., A Companion to Early TwentiethCentury Britain, Oxford, Blackwell, 2003a.

Emsley, Clive, The Police, in Bogdanor, Vernon ed., The British Constitution in the Twentieth Century, Oxford: Oxford University Press for the British Academy, 2003b.

Emsley, Clive, Crime and Society in England, 1750-1900, $3^{\text {rd }}$ edition, London, Longman, 2004.

Emsley, Clive, Hard Men: The English and Violence since 1750, London, Hambledon, 2005. 
Englander, David, Henry Mayhew and the Criminal Classes of Victorian England: The Case Reopened, in Knafla, Louis A. ed. Crime, Gender and Sexuality in Criminal Prosecutions: Criminal Justice History, vol. 17, Westport, Conn., Greenwood Press, 2002.

Finnane, Mark, A decline in violence in Ireland? Crime, policing and social relations, 1860-1914, Crime, histoire \& sociétés/Crime, history \& societies, 1997, 1, 1, pp. 51-70.

Fletcher, Richard, Bloodfeud: Murder and Revenge in Anglo-Saxon England, London, Allen Lane, 2002.

Forsythe, William James, The Reform of Prisoners 1830-1900, London, Croom Helm, 1987.

Forsythe, William James, Penal Discipline, Reformatory Projects and the English Prison Commission, 1895-1939, Exeter, Exeter University Press, 1990.

Gaskell, Malcolm, Crime and mentalities in early modern England, Cambridge, Cambridge University Press, 2000.

Gatrell, V.A.C., The Hanging Tree: Execution and the English People 1770-1868, Oxford, Oxford University Press, 1994.

Godfrey, Barry S., Workplace appropriation and the gendering of factory «law»: West Yorkshire, 1840-1880, in Arnot, Margaret J., Usborne, Cornelie eds., Gender and Crime in Modern Europe, London, UCL Press, 1999a.

Godfrey, Barry S., The Impact of the Factory on Workplace Appropriation in Mid to Late Nineteenth-Century Yorkshire, British Journal of Criminology, 1999b, 39, 1, pp. 56-71.

Godfrey, Barry S., Judicial impartiality and the use of criminal law against labour: The sentencing of workplace appropriators in Northern England, 1840-1880, Crime, histoire \& sociétés/Crime, history \& society, 1999c, 3, 2, pp. 57-72.

Godfrey, Barry S., «Private Policing and the workplace»: The Worsted Committee and the Policing of Labor in Northern England, 1840-1880, in Knafla, Louis A. ed. Policing and War in Europe: Criminal Justice History, vol. 16, Westport, Conn., Greenwood Press, 2002.

Godfrey, Barry S., Locker, John P., The Nineteenth-Century Decline of Custom, and its Impact on Theories of «Workplace Theft» and «White Collar» Crime, Northern History, 2001, 38, pp. 261-273.

Goldsmith, Alistair Lindsay, The Development of the City of Glasgow Police c.1800-1939, unpublished Ph. D thesis, University of Strathclyde, 2002.

Grace, Susan E., Female Criminality in York and Hull, 1830-1870, unpublished D. Phil thesis, University of York, 1998.

Harris, Andrew T., Policing the City: Crime and Legal Authority in London, 1780-1840, Columbus Ohio, Ohio State University Press, 2004.

Hay, Douglas, Property, Authority and the Criminal Law, in Hay, Douglas, Linebaugh, Peter, Thompson E.P. et al., Albion's Fatal Tree: Crime and Society in Eighteenth-Century England, London, Allen Lane, 1975.

Hay, Douglas, Patronage, Paternalism and Welfare: Masters, Workers and Magistrates in late Eighteenth-Century England, International Labour and Working-Class History, 1998, 53, pp. 27-48.

Hay, Douglas, Master and Servant in England: Using the Law in the Eighteenth and Nineteenth Centuries, in Steimetz, Willibald ed., Private Law and Social Inequality in the Industrial Age: Comparing Legal Cultures in Britain, France, Germany and the United States, Oxford, Oxford University Press, 2000. 
Hitchens, Peter, A Brief History of Crime: The Decline of Order, Justice and Liberty in England, London, Atlantic Books, 2003.

Ignatieff, Michael, A Just Measure of Pain: The Penitentiary in the Industrial Revolution 1750-1850, London, Macmillan, 1978.

Jackson, Louise A., Child Sexual Abuse in Victorian England, London, Routledge, 2000.

Jackson, Louise A., «Lady Cops» and «Decoy Doras»: Gender, Surveillance and the Construction of Urban Knowledge, 1919-59, London Journal, 2002, 27, 1, pp. 63-83.

Jackson, Louise A., Care or Control? The Metropolitan Police and Child Welfare, 1919-1969, Historical Journal, 2003, 46, 3, pp. 623-648.

Jackson, Mark, New-Born Child Murder: Women, illegitimacy and the courts in eighteenth-century England, Manchester, Manchester University Press, 1996.

Jackson, Mark, ed., Infanticide: Historical Perspectives on Child Murder and its Concealment, 1500-2000, Aldershot, Ashgate, 2001.

Jones, David J.V., Crime in Nineteenth-Century Wales, Cardiff, University of Wales Press, 1992.

Jones, David J.V., Crime and Policing in the Twentieth Century: The South Wales Experience, Cardiff, University of Wales Press, 1996.

Kermode, Jenny, Walker, Garthine, eds., Women, Crime and the Courts in Early Modern England, London, UCL Press, 1994.

Kilday, Anne-Marie, Women and Crime in South-West Scotland: A Study of the Justiciary Court Records 1750-1815, unpublished Ph.D thesis, University of Strathclyde, 1998.

King, Peter, Female Offenders, Work and Life-Cycle Change in late-Eighteenth-Century London, Continuity and Change, 1996, 11, 1, pp. 61-90.

King, Peter, The Rise of Juvenile Delinquency in England 1780-1840: Changing Patterns of Perception and Prosecution, Past and Present, 1998, 160, pp. 116-166.

King, Peter, Gender, Crime and Justice in late Eighteenth- and early Nineteenth-Century England, in Arnot Margaret L., Usborne, Cornelie eds., Gender and Crime in Modern Europe, London, UCL Press, 1999.

King, Peter, Crime, Justice and Discretion in England 1740-1820, Oxford, Oxford University Press, 2000.

King, Peter, Summary Justice and Social Relations in Eighteenth-Century England, Past and Present, 183, 2004, pp. 125-172.

Langbein, John H., The Origins of the Adversary Criminal Trial, Oxford, Oxford University Press, 2003. Lawrence, Paul, «Images of poverty and crime»: Police memoirs in England and France at the end of the nineteenth century, Crime, histoire \& sociétés/Crime, history \& societies, 2000, 4, 1, pp. 63-82.

Lawrence, Paul, «Scoundrels and scallywags and some honest men...»: Memoirs and the selfimage of French and English policemen c.1870-1939, in Godfrey, Barry S., Emsley Clive, Dunstall, Graeme eds., Comparative Histories of Crime, Cullompton, Willan Publishing.

Leneman, Leah, «A tyrant and a tormentor»: Violence against wives in eighteenth- and early nineteenth-century Scotland, Continuity and Change, 1997, 12, 1, pp. 31-54.

Locker, John P., «This most pernicious species of crime»; embezzlement in its public and private dimensions, c. 1850-1930, unpublished Ph.D thesis, Keele University, 2004.

McConville, Seán, Next Only to Death: English Local Prisons 1860-1900, London, Routledge, 1995. 
McGowan, John, The Emergence of Modern Civil Police in Scotland: A Case Study of the Police and Systems of Police in Edinburghshire, 1800-1833, unpublished Ph.D thesis, the Open University, 1997.

McGowen, Randall, Civilizing Punishment: The End of the Public Execution in England, Journal of British Studies, 1994, 33, pp. 257-282.

McGowen, Randall, From Pillory to Gallows: The Punishment of Forgery in the age of the Financial Revolution, Past and Present, 1999, 165, pp. 107-140.

McGowen, Randall, Revisiting the Hanging Tree: Gatrell on Emotion and History, British Journal of Criminology, 2000, 40, 1, pp. 1-13.

McGowen, Randall, History, Culture and the Death Penalty: The British Debates, 1840-1870, Historical Reflections/Réflexions historiques, 2003, 29, 2, pp. 229-249.

Malcolm, Joyce Lee, Guns and Violence: The English Experience, Cambridge, Mass. and London, Harvard University Press, 2002.

May, Allyson N., The Bar and the Old Bailey, 1750-1850, Chapel Hill, N.C. and London, University of North Carolina Press, 2003.

Morgan, Gwenda, Rushton, Peter, Rogues, thieves and the rule of law: The problem of law enforcement in north-east England, 1718-1800, London, UCL Press, 1998.

Morgan, Gwenda, Rushton, Peter, The Justicing Notebook (1750-1764) of Edmund Tew, Rector of Bolden, Woodbridge, Surtees Society, 2000.

Morgan, Gwenda, Rushton, Peter, The Magistrate, the Community and the Maintenance of an Orderly Society in Eighteenth-Century England, Historical Research, 2003a, 76, 4, pp 54-77.

Morgan, Gwenda, and Rushton, Peter, «Running away and returning home: the fate of English convicts in the American colonies», Crime, histoire \& sociétés/Crime, history \& societies, 2003b, 7, 2, pp. 61-80.

Morgan, Gwenda, Rushton, Peter, Eighteenth-Century Criminal Transportation, Houndmills Basingstoke, Palgrave Macmillan, 2004.

Morris, Robert M., «Lies, damned lies and criminal statistics»: reinterpreting the criminal statistics in England and Wales, Crime, histoire \& sociétés/Crime, history \& societies, 2001, 5, 1, pp. 111-127.

Morris, Robert M., The Metropolitan Police and Government, 1860-1920, unpublished Ph.D thesis, the Open University, 2004.

Oram, Gerard, Worthless Men: Race, Eugenics and the Death Penalty during the First World War, London, Francis Bootle, 1998.

Oram, Gerard, «The administration of discipline by the English is very rigid»: British Military Law and the Death Penalty (1868-1918), Crime, histoire \& sociétés/Crime, history \& societies, 2001, 5, 1, pp. 93-110.

Oram, Gerard, Pious Perjury: Discipline and Morale in the British Force in Italy, 1917-1918, War in History, 2002, 9, 4, pp. 412-430.

Oram, Gerard, Military Executions during World War One, Houndmills Basingstoke, Palgrave Macmillan, 2003.

Oxley, Deborah, Convict Maids: The Forced Migration of Women to Australia, Cambridge, Cambridge University Press, 1996. 
Palk, Dierdre E.P., Gender, Crime and Discretion in the English Criminal Justice System, 1780s to 1830s, unpublished Ph.D thesis, University of Leicester, 2002.

Palk, Dierdre, Private Crime in Public and Private Places: Pickpockets and Shoplifters in London 1780 to 1823, in Hitchcock Tim, Shore, Heather eds., The Streets of London: From the Great Fire to the Great Stink, London, Rivers Oram Press, 2003.

Palk, Dierdre, «Fit Objects for Mercy»: Gender, the Bank of England and Currency Criminals, 1804-1833, Women's Writing, 2004, 11, pp. 237-258.

Petrow, Stefan, Policing Morals: The Metropolitan Police and the Home Office 1870-1914, Oxford, Clarendon Press, 1994.

Philips, David, William Augustus Miles (1796-1851): Crime, Policing and Moral Entrepreneurship in England and Australia, Melbourne, University of Melbourne Press, 2001.

Philips, David, Three «moral entrepreneurs» and the creation of a «criminal class» in England, c. 1790s-1840s, Crime, histoire \& sociétés/Crime, history \& societies, 2003, 7, 1, pp. 79-107.

Philips, David, Storch, Robert D., Whigs and Coppers: The Grey Ministry's National Police Scheme, 1832, Historical Research, 1994, 67 (no. 162) pp. 75-90.

Philips, David, Storch, Robert D., Policing Provincial England 1829-1856: The Politics of Reform, London and New York, Leicester University Press, 1999.

Rawlings, Philip, Crime and Power: A History of Criminal Justice 1688-1998, London, Longman, 1999.

Reynolds, Elaine A., Before the Bobbies: The Night Watch and Police Reform in Metropolitan London, 1720-1830, Houndmills Basingstoke, Macmillan, 1998.

Reynolds, Elaine A., Sir John Fielding, Sir Charles Whitworth, and the Westminster Night Watch Act, 1770-1775, in Knafla, Louis A. ed., Policing and War in Europe, Criminal Justice History, vol. 16, Westport, Conn., Greenwood Press, 2002.

Roodhouse, Mark, The 1948 Belcher Affair and Lynskey Tribunal, Twentieth-Century British History, 2002, 13, 4, pp. 384-411.

Roodhouse, Mark, Black-market activity in Britain 1939-1955, unpublished Ph.D thesis, University of Cambridge, 2003a.

Roodhouse, Mark, The «Ghost Squad»: Undercover Policing in London, 1945-49, in Gerard Oram, ed. Conflict and Legality: Policing in Mid-Twentieth-Century Europe, London, Francis Boutle, 2003b.

Shakesheff, Timothy, Rural Conflict, Crime and Protest: Herefordshire, 1800-1860, Woodbridge, Boydell Press, 2003.

Sharpe, James A., Crime in Early Modern England 1550-1750, $2^{\text {nd }}$ edition, London, Longman, 1998.

Sharpe, James A., The Bewitching of Anne Gunter, London, Profile Books, 1999.

Shoemaker, Robert, Male Honour and the Decline of Public Violence in Eighteenth-Century London, Social History, 2001, 26, pp. 190-203.

Shoemaker, Robert, The Taming of the Duel: Masculinity, Honour and Ritual Violence in London, 1660-1800, Historical Journal, 2002, 45, pp. 525-545.

Shoemaker, Robert, The London Mob, London, Hambledon, 2004.

Shore, Heather, Artful Dodgers: Youth crime in early nineteenth-century London, Woodbridge, Royal Historical Society/Boydell Press, 1999. 
Shpayer-Makov, Haia, The making of a Policeman: A social history of a labour force in Metropolitan London, 1829-1914, Aldershot, Ashgate, 2002.

Taylor, David, Crime Policing and Punishment in England, 1750-1914, Houndmills Basingstoke, Macmillan, 1998.

Taylor, David, Policing the Victorian Town: The Development of the Police in Middlesbrough c.1840-1914, Houndmills Basingstoke, Palgrave Macmillan, 2002.

Taylor, Howard, Rationing Crime: The political economy of criminal statistics since the 1850s, Economic History Review, 1998a, 51, 3, pp. 569-590.

Taylor, Howard, The politics of the rising crime statistics of England and Wales, 1914-1960, Crime, histoire \& sociétés/Crime, history \& societies, 1998b, 2, 1, pp. 5-28.

Taylor, Howard, Forging the Job: A Crisis of «Modernization» or Redundancy for the Police in England and Wales, 1900-39, British Journal of Criminology, 1999, 39, 1, pp. 113-135.

Thomas, Donald, An Underworld at War: Spivs, Deserters, Racketeers and Civilians in the Second World War, London, John Murray, 2003.

Wall, David S., The Chief Constables of England and Wales: The socio-legal history of a criminal justice elite, Aldershot, Ashgate, 1998.

Watson, Katherine, Poisoned Lives: English Poisoners and their Victims, London, Hambledon, 2004.

Weinberger, Barbara, The Best Police in the World: An Oral History of English Policing, Aldershot, Scholar Press, 1995.

Whitfield, James, The Metropolitan Police: alienation, culture and relations with London's Caribbean Community 1950-70, Crime, histoire \& sociétés/Crime, history \& societies, 2003, 7, 2, pp. 23-39.

Whitfield, James, Unhappy Dialogue: The Metropolitan Police and black Londoners in post-war Britain, Cullompton, Willan Publishing, 2004.

Wiener, Martin J., The Victorian Criminalization of Men, in Spierenburg, Pieter ed., Men and Violence: Gender, Honor and Rituals in Modern Europe and America, Columbus, Ohio: Ohio State University Press, 1998.

Wiener, Martin J., The sad story of George Hall: Adultery, murder and the politics of mercy in mid-Victorian England, Social History, 1999a, 24, 2, pp. 174-195.

Wiener, Martin J., Judges v. Jurors: Courtroom Tensions in Murder Trials and the Law of Criminal Responsibility in Nineteenth-Century England, Law and History Review, 1999b, 17, 3, pp. 467-506.

Wiener, Martin J., Men of Blood: Violence, Manliness and Criminal Justice in Victorian England, Cambridge, Cambridge University Press, 2004.

Williams, Chris A., Counting crimes or counting people: some implications of mid-nineteenthcentury British police returns, Crime, histoire \& sociétés/Crime, history \& societies, 2000a, 4, 2, pp. 77-93.

Williams, Chris A., Expediency, Authority and Duplicity: Reforming Sheffield's Police, 1832-1840, in Morris Robert J., Trainor, Richard H. eds., Urban Governance: Britain and Beyond, Aldershot, Ashgate, 2000b.

Williams, Chris A., Catégorisation et stigmatisation policières à Sheffield, au milieu du XIX ${ }^{\mathrm{e}}$ siècle, Revue d'histoire moderne et contemporaine, 2003, 50, 1, pp. 104-125. 
Williams, Chris A., The Sheffield Democrats' Critique of Criminal Justice in the 1850s, in Colls Robert, Rodger, Richard eds., Cities of Ideas: Urban Governance in Britain, 1800-2000, Aldershot, Ashgate, 2004.

Wilson, Sarah, Invisible Criminals? Legal, Social and Cultural Perspectives on Financial Crime in Britain 1800-1930, unpublished Ph.D thesis, University of Wales, Swansea, 2003.

Wood, J. Carter, Self-policing and the policing of the self: Violence, protection and the civilizing bargain in Britain, Crime, histoire \& sociétés/Crime, history \& societies, 2003, 7, 1, pp. 109-128.

Wood, J. Carter, Violence and Crime in Nineteenth-Century England: The Shadow of our Refinement, London, Routledge, 2004

\section{NOTES}

1. My thanks to my colleagues, Peter King, Paul Lawrence and Chris A.Williams, for their helpful comments on earlier drafts of this essay.

2. Fletcher (2002).

3. Gaskill (2000).

4. Kermode, Walker (1994).

5. Sharpe (1999).

6. Godfrey (1999b, 1999c, 2002). See also Hay (2000).

7. Godfrey, Locker (2001).

8. McGowen (1999). See also the important micro history of the fraud involving the Perreau brothers and Mrs Rudd, Andrew, McGowen (2001)

9. Wilson (2003); Locker (2004); Colley (2001 and forthcoming).

10. King (2004), and see also Hay $(1998,2000)$ and Morgan, Rushton $(2000,2003 a)$.

11. Shore (1999). There is also an important discussion of the perception and prosecution of juvenile delinquency in the late eighteenth and early nineteenth centuries in King (1998).

12. Cox (2003). Cox and Shore have collaborated to edit a useful collection of essays that compare the development of youth delinquency across Europe and over an extended time frame. Cox and Shore (2002)

13. There are some important exceptions; for the early modern period see, Kermode and Walker (1994) and for the eighteenth and nineteenth centuries see, Godfrey (1999a); Grace (1998); King (1996); Palk (2002, 2003, 2004).

14. King (1999).

15. Morgan, Rushton (1998); Taylor (2002); Shakesheff (2003).

16. Archer (1990).

17. Archer (1999).

18. Beattie (2001)

19. Harris (2004).

20. Reynolds (1998, 2002).

21. Dodsworth (2004).

22. Philips, Storch (1994).

23. Philips, Storch (1999).

24. Petrow (1994).

25. Shpayer-Makov (2002, p. 7).

26. Williams (2000b, 2004).

27. Wall (1998). Wall's and Shpayer-Makov's work is usefully supplemented by Morris (2004) who analyses the senior officers of the Metropolitan Police of London. 
28. King (2000).

29. Hay (1975).

30. Langbein (2003, p. 343).

31. May (2003).

32. Cairns (1998).

33. Gatrell (1994).

34. Ignatieff (1978).

35. De Lacy (1986); Forsythe (1987 and 1990); McConville (1995).

36. McGowen (2002); Devereaux (2004).

37. McGowen (1994, 2003).

38. Bailey (2000).

39. Morgan, Rushton $(2003,2004)$.

40. Oxley (1996). More generally on the convicts transported to Australia see the essays in Duffield and Bradley (1997).

41. Brown (2003).

42. Briggs, Harrison, McInnes, Vincent (1996).

43. Barrett, Harrison (1999).

44. Sharpe (1998); Emsley (2004).

45. Taylor (1998); Rawlings (1999).

46. Jones $(1992,1996)$.

47. Emsley (2004, p. 21).

48. Taylor (1998b).

49. Taylor (1998a, 1999).

50. Morris (2001, p. 117).

51. Williams (2000).

52. Williams (2003)

53. Corns, Hughes-Wilson (2001).

54. Oram (1998, 2001, 2002, 2003).

55. Eder (2004) is an exception.

56. Malcolm (2002).

57. Hitchens (2003, chapter 5).

58. Brown, Barrett (2002).

59. Jackson (2000, p. 131).

60. Jackson (1996).

61. Jackson (2001).

62. D'Cruze (1998).

63. D'Cruze (2000).

64. Davies (1998, 1999, 2000).

65. Wood (2004). See also, Wood (2003).

66. Emsley (2005).

67. Shoemaker (2001, 2002 and see also 2004).

68. Wiener (2004). See also, Wiener (1998, 1999a, 1999b).

69. Ballinger (2000, p. 330).

70. Watson (2004).

71. Philips (2001, 2003); Englander (2002).

72. Lawrence $(2000,2003)$.

73. Emsley (1996, 2003); Weinberger (1995).

74. Jackson $(2002,2003)$.

75. Jones (1996)

76. Thomas (2003). 
77. Emsley (2002, 2005).

78. Roodhouse (2002, 2003a, 2003b).

79. Whitfield (2003, 2004).

80. Finnane (1997); Conley (1995, 1999a, 1999b).

81. Crowther (1998); Leneman (1997); McGowan (1997); Kilday (1998); Barrie (2001); Goldsmith (2002); Brown, Ferguson (2002).

AUTHOR

\section{CLIVE EMSLEY}

The Open University, ICCCR, Walton Keynes, MK7 6AA Milton Keynes - U.K, c.emsley@open.ac.uk 